\title{
Hormonal and Lactational Responses to Growth Hormone-Releasing Hormone Treatment in Lactating Japanese Black Cows
}

\author{
H. Shingu, ${ }^{1}$ K. Hodate, ${ }^{2}$ S. Kushibiki, ${ }^{1, *}$ Y. Ueda, ${ }^{1}$ E. Touno, ${ }^{1}$ \\ M. Shinoda, ${ }^{1,}+$ and S. Ohashi ${ }^{3}$ \\ ${ }^{1}$ Department of Animal Production and Grasslands Farming, \\ National Agricultural Research Center for Tohoku Region, \\ Morioka, Iwate, 020-0198, Japan \\ ${ }^{2}$ School of Veterinary Medicine and Animal Sciences, \\ Kitasato University, Towada, Aomori, 034-8628, Japan \\ ${ }^{3}$ National Institute of Advanced Industrial Science and Technology, \\ Tsukuba, Ibaraki, 305-8561, Japan
}

\begin{abstract}
Ten multiparous lactating Japanese Black cows (beef breed) were used to evaluate the effects of bovine growth hormone-releasing hormone (GHRH) analog on milk yield and profiles of plasma hormones and metabolites. The cows received 2 consecutive 21-d treatments (a daily s.c. injection of 3-mg GHRH analog or saline) in a 2 (group) $\times 2$ (period) Latin square crossover design. The 5 cows in group A received GHRH analog during period 1 (from d 22 to 42 postpartum) and saline during period 2 (from d 57 to 77 postpartum), and those in group B received saline and GHRH analog during periods 1 and 2, respectively. Mean milk yield decreased in saline treated compared with that during the 1-wk period before treatment 7.4 and $19.1 \%$ during periods 1 (group B) and 2 (group A), respectively. Treatment with GHRH analog increased milk yield $17.4 \%$ (period 1, group A) and 6.3\% (period 2, group B). Treatment with GHRH analog induced higher basal plasma concentrations of growth hormone (GH), insulin-like growth factor-1 (IGF-1), insulin, and glucose compared with saline-treated cows. In glucose challenge, the GHRH analog-treated beef cows had greater insulin secretion than the saline-treated beef cows. In insulin challenge, however, there were no significant differences in the areas surrounded by hypothetical lines of basal glucose concentrations and glucose response curves between GHRH analog- and saline-treated cows. These results demonstrate that
\end{abstract}

Received July 8, 2003.

Accepted September 8, 2003.

Corresponding author: H. Shingu; e-mail: shinguu@affrc.go.jp.

"Current address: Department of Animal Physiology and Nutrition, National Institute of Livestock and Grassland Science, Tsukuba, Ibaraki, 305-0901, Japan.

Current address: Department of Integrated Research for Agriculture, National Agricultural Research Center for Hokkaido Region, Memuro, Hokkaido, 082-0071, Japan.
GHRH analog treatment facilitates endogenous $\mathrm{GH}$ secretion in lactating Japanese Black cows, leading to increases in milk yield and plasma concentrations of IGF-1, insulin, and glucose.

(Key words: bovine growth hormone-releasing hormone, hormone, milk yield, Japanese Black cow)

Abbreviation key: A15-DAbGHRH = analog with D-Ala and Ala substitutions in position-2 Ala and -15 Gly of bovine GHRH (1-29)- $\mathrm{NH}_{2}$, respectively, AUC = area under the response curve, $\mathbf{d A U C}=$ decreased AUC, $\mathbf{G H}=$ growth hormone, $\mathbf{G H R H}=$ growth hormone-releasing hormone, IGF-1 = insulin-like growth factor-1.

\section{INTRODUCTION}

In lactating dairy cows, growth hormone (GH) exerts galactopoietic and lipolytic effects, leading to a preferential partition of nutrients to mammary glands and an enhancement of milk yield (Bauman and Currie, 1980). The coordinated control of the metabolism of maternal body tissues to support a preferred physiological state such as lactation is explained as homeorhesis, and GH is a key hormone for the homeorhetic regulation. It appears that the homeorhetic control is different between lactating dairy and beef cows (Hart et al., 1975; Shingu et al., 2002b), which likely results from the difference of $\mathrm{GH}$ secretion (Shingu et al., 2002b).

Japanese Black cattle (beef type), long raised in Japan for the production of meat preferred by Japanese consumers, have a major characteristic of markedly lower milk production with peak lactation at 2 to 3 wk postpartum compared with that of Holstein cattle (dairy type) (Shingu et al., 2002a). The beef cows also have markedly lower basal and growth hormone-releasing hormone (GHRH)-induced GH secretion than the dairy cows during lactation. In addition, there were similar basal GH concentrations throughout lactation 
(Shingu et al., 2002b). However, even in the beef breed, changes in milk yield and components and plasma levels of hormones and metabolites may be accompanied by an increase in endogenous GH secretion after GHRH treatment.

In beef type cattle such as Hereford-cross (Bines et al., 1980), Angus, and Charolais (Armstrong et al., 1995), treatment with bovine GH, namely somatotropin, during lactation enhanced milk yield (reviewed by Peel and Bauman, 1987; Bauman, 1992; Burton et al., 1994). In addition, the administration of somatotropin also led to an increase in plasma concentrations of insulin-like growth factor-1 (IGF-1) and NEFA (Schams et al., 1991; Armstrong et al., 1995). However, the effect of somatotropin treatment on plasma glucose and insulin levels varies. For example, following administration of somatotropin, serum concentrations of insulin and glucose increased in lactating Angus and Charolais cows (Armstrong et al., 1995), but insulin concentrations and glucose showed no change or changes within physiological ranges in Deutches Fleckvieh cows (Schams et al., 1991). Thus, in lactating beef cows, it is controversial whether substantial changes in insulin and glucose concentrations are induced by exogenous GH treatment. Moreover, the effects of consecutive exogenous GHRH treatment on milk yield and milk components, and on the secretion of GH, IGF-1, and insulin, and the plasma concentrations of glucose and NEFA remain unknown.

The aim of the present study was to examine the changes in milk yield and components and the profiles of hormones and metabolites in a typical beef breed with extremely low milk production, Japanese Black cows, that received daily s.c. GHRH treatment.

\section{MATERIALS AND METHODS}

\section{Animals and Feeding}

Ten multiparous lactating Japanese Black cows were used from d 14 to 84 postpartum. All procedures involving these animals were approved by the Guide for the Care and Use of Experimental Animals (National Agricultural Research Center for Tohoku Region, Animal Care Committee). Cattle were housed in a stanchion barn throughout the experiment.

The feed was composed of timothy-grass hay, corn silage, alfalfa hay cube, and concentrate (TDN 70.0\%, DCP $15.5 \%)$. The cows were provided the feed twice daily ( 0830 and $1630 \mathrm{~h}$ ) with free access to water and trace-mineralized salt. The quantity of feed offered was formulated to meet the nutrient requirements for maintenance and lactation according to the Japanese Feeding Standard for Beef Cattle (1995). In addition to weekly measurement of $\mathrm{BW}$, the animals were

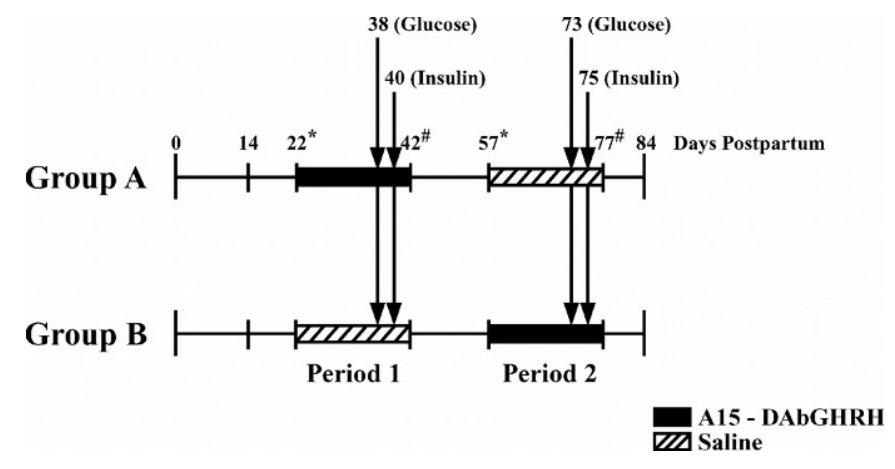

Figure 1. Schematic representation of the experimental design. Closed and hatched columns represent the periods of 21-d s.c. treatment of bovine growth hormone (GH)-releasing hormone analog (A15DAbGHRH, $3 \mathrm{mg} / \mathrm{d}$ ) and saline, respectively. "Glucose" and "Insulin" indicate glucose and insulin challenge day performed. Asterisks and sharps indicate the first and final days of the treatments.

weighed at the day before the challenge to adjust the dose of glucose or insulin injected. In the present experiment, the feed quantity was not adjusted except at $\mathrm{d} 14$ and 49 postpartum ( $8 \mathrm{~d}$ before the beginning of the respective treatment periods). During the experimental days, no animals received artificial inseminations.

The cows were fed the diets between 0830 and 1030 $\mathrm{h}$ and between 1630 and $1930 \mathrm{~h}$. On the first and final days of periods 1 and 2 and on the days of glucose and insulin challenges (see Figure 1), a unilateral catheter was inserted into the jugular vein by $1030 \mathrm{~h}$, and thereafter the animals were left undisturbed.

\section{Experimental Procedures}

Ten cows were weighed on the first day of the present experiment (d 14 postpartum) and subsequently divided randomly into 2 groups of 5 (groups A and B). The mean BW ( $\pm \mathrm{SE}$ ) were $527.4 \pm 8.8 \mathrm{~kg}$ (group A) and $514.4 \pm 7.3 \mathrm{~kg}$ (group B). As shown in the schematic representation of the experiment (Figure 1), during period 1 (from d 22 to 42 postpartum) or period 2 (from d 57 to 77 postpartum) the animals received daily s.c. injections of $5 \mathrm{~mL}$ of saline or saline containing $3 \mathrm{mg}$ of bovine GHRH analog (A15-DAbGHRH; an analog with D-Ala and Ala substitutions in position-2 Ala and 15 Gly of bovine GHRH (1-29)- $\mathrm{NH}_{2}$, respectively. Animals were treated in a 2 (group) $\times 2$ (period) Latin square crossover experimental design. Group A received A15-DAbGHRH administration during period 1 and saline during period 2, while group B received saline and A15-DAbGHRH during periods 1 and 2, respectively. Injections were given at $1200 \mathrm{~h}$.

After calving, cows were milked twice daily (0600 and $1600 \mathrm{~h}$ ) using a milking machine, and the milk 
yield was recorded at every milking. Aliquots of the milk samples collected were stored at $-30^{\circ} \mathrm{C}$ until assayed for the percentages of milk components (milk fat, milk protein, and lactose) using an infrared spectrometer (Milko-Scan 134A/B; Foss Electric Co., Hillerd, Denmark). To compare the effects of consecutive A15-DAbGHRH and saline treatment on milk production, the milk yields during and after each period were represented as percentages by normalizing the value during the 1-wk period before the respective period as $100.0 \%$.

Throughout the experimental duration, $10-\mathrm{mL}$ blood samples from the jugular vein were collected every other day into heparinized syringes at $1200 \mathrm{~h}$ to measure basal plasma concentrations of GH, IGF-1, insulin, glucose, and NEFA. During periods 1 and 2, the blood samples were collected just before the injections.

Changes in plasma GH concentrations during the $12 \mathrm{~h}$ after A15-DAbGHRH or saline injection were investigated on the first and final days of each period (period 1: d 22 and 42 postpartum; period 2: $\mathrm{d} 57$ and 77 postpartum). Blood samples ( $4 \mathrm{~mL})$ were collected preinjection $(-30,-15$, and $0 \mathrm{~min})$, at 15 -min intervals for the first $6 \mathrm{~h}$ (from 1200 to $1800 \mathrm{~h}$ ), and thereafter at 30-min intervals (from 1800 to $2400 \mathrm{~h}$ ) via an indwelling catheter previously inserted into one of the jugular veins.

To examine the changes in insulin secretion under the consecutive A15-DAbGHRH or saline injection, glucose solution $(112.5 \mathrm{mg} / \mathrm{kg}$ of BW, Otsuka Pharmaceutical Co., Ltd., Tokyo, Japan) was injected at 1200 $\mathrm{h}$ via a catheter on $\mathrm{d} 38$ (period 1) and 73 postpartum (period 2), as shown in Figure 1. Likewise, bovine insulin $(0.2 \mathrm{U} / \mathrm{kg}$ of BW, Wako Pure Chemical Industries Ltd., Osaka, Japan) was injected at $1200 \mathrm{~h}$ on d 40 (period 1) and 75 postpartum (period 2) to examine the glucose response to insulin. During a glucose challenge, a series of blood samples $(4 \mathrm{~mL})$ were collected at $-30,-15,0$ (just before the injection), $5,10,15,20$, $30,45,60,90$, and $120 \mathrm{~min}$ after glucose injection. During an insulin challenge, blood samples $(4 \mathrm{~mL})$ were obtained at $-30,-15,0,5,10,15,20,30,45,60$, $75,90,105,120,150,180,210$, and $240 \mathrm{~min}$ after insulin injection.

\section{Analytical Methods}

All blood samples were immediately chilled on ice, and plasma was obtained by centrifugation $(25 \mathrm{~min}$ at $1600 \times g)$ at $4^{\circ} \mathrm{C}$ and stored at $-30^{\circ} \mathrm{C}$.

Plasma concentrations of GH and IGF-1 were determined by radioimmunoassay, as described by Johke (1978) and Ozawa et al. (1991), respectively. Plasma insulin concentrations were measured using a com- mercial radioimmunoassay kit (Insulin Eiken RIA kit; Eiken Chemical Co., Ltd., Tokyo, Japan). Intra- and interassay coefficients of variation were 7 and $11 \%$ for GH, 5 and $12 \%$ for IGF-1, and 2.5 and $9.1 \%$ for insulin, respectively. Plasma concentrations of glucose and NEFA were determined using a commercially available colorimetric kit: Glucose 2-HA and NEFA-HA Test Wako (Wako Pure Chemical Industries Ltd., Osaka, Japan), respectively, using a Hitachi 7070 auto-analyzer (Hitachi Ltd., Tokyo, Japan).

\section{Calculations}

On both the first and final days of periods 1 and 2, the area under the response curve (AUC) of GH released during $12 \mathrm{~h}$ (from 1200 to $2400 \mathrm{~h}$ ) in response to A15DAbGHRH or saline was calculated. As an index of the amount of insulin secretion in response to glucose, total insulin AUC during 120 min (from 1200 to 1400 h) was calculated. Likewise, net insulin AUC was also measured. This net AUC is the increased AUC after glucose injection. Moreover, as an indicator of the amount of glucose utilized by body tissues following insulin injection, we subtracted the area under the glucose response curve during $240 \mathrm{~min}$ (from 1200 to $1600 \mathrm{~h}$ ) from the area under a hypothetical line (the mean of basal glucose concentration). This residual area was designated the "decreased AUC (dAUC)," as previously described (Shingu et al., 2001, 2002b).

\section{Statistical Analysis}

The data were subjected to 2-way repeated-measures ANOVA using statistical software for Macintosh (STATVIEW version 5.0, Abicus, CA). All values are expressed as the mean $\pm \mathrm{SE}$. Differences were designated statistically significant when $P<0.05$. The significance of differences among mean values on a given experimental day (period) of plasma hormone and metabolite concentrations, milk yield and components, and AUC, was determined using Fisher's PLSD posthoc test, if a significant effect of treatment or treatment $\times$ day (period) was found.

\section{RESULTS}

\section{Milk Yield and Milk Components}

The changes in daily milk yield during the experimental days are depicted in Table 1 and Figure 2. Consecutive treatment with A15-DAbGHRH induced increases in daily milk yield of $17.4 \%$ during period 1 (group A) and 6.3\% during period 2 (group B), as compared with that during the 1-wk period before treatment. Daily milk production in saline-treated 
Table 1. Relative average milk yield during and after daily injection of bovine growth hormone-releasing hormone analog (A15-DAbGHRH) or saline in lactating Japanese Black cows. ${ }^{1,2,3}$

\begin{tabular}{|c|c|c|c|c|c|c|}
\hline \multirow[b]{2}{*}{ Days $\mathrm{PP}^{4}$} & \multicolumn{3}{|c|}{$22-42($ period 1$)$} & \multicolumn{3}{|c|}{$57-77($ period 2$)$} \\
\hline & $14-21$ & $\begin{array}{l}22-42 \\
\text { (period 1) }\end{array}$ & $43-49$ & $50-56$ & $\begin{array}{l}57-77 \\
(\text { period 2) }\end{array}$ & $78-84$ \\
\hline Group A & $100.0 \%^{5}$ & $117.4 \% *$ & $115.4 \% *$ & $100.0 \%$ & $80.9 \%$ & $67.4 \%$ \\
\hline Group B & $100.0 \%$ & $92.6 \%$ & $83.3 \%$ & $100.0 \%$ & $106.3 \% * *$ & $100.3 \% *$ \\
\hline
\end{tabular}

${ }^{1}$ Group A: 5 cows treated with A15-DAbGHRH (period 1) and saline (period 2).

${ }^{2}$ Group B: 5 cows treated with saline (period 1) and A15-DAbGHRH (period 2).

$3 * P<0.05$; and $* * P<0.01$ compared with the saline-treated group.

${ }^{4} \mathrm{PP}:$ postpartum.

${ }^{5}$ Average milk yield for $1 \mathrm{wk}$ before each period is taken as $100.0 \%$.

cows decreased $7.4 \%$ during period 1 (group B) and $19.1 \%$ during period 2 (group A). However, there were no significant differences in milk components (fat, protein, and lactose) between the groups treated with A15-DAbGHRH and saline (data not shown).

\section{Basal Plasma Concentrations of Hormones and Metabolites}

Consecutive A15-DAbGHRH-treated cows tended to have higher basal plasma concentrations of GH, IGF1 , insulin, and glucose than saline-treated cows during both periods (Table 2). Especially, the IGF-1 concentrations of the A15-DAbGHRH-treated cows continued to be elevated for $7 \mathrm{~d}$ after the secession of treatment. On the other hand, A15-DAbGHRH injection scarcely altered the basal NEFA concentrations in plasma.

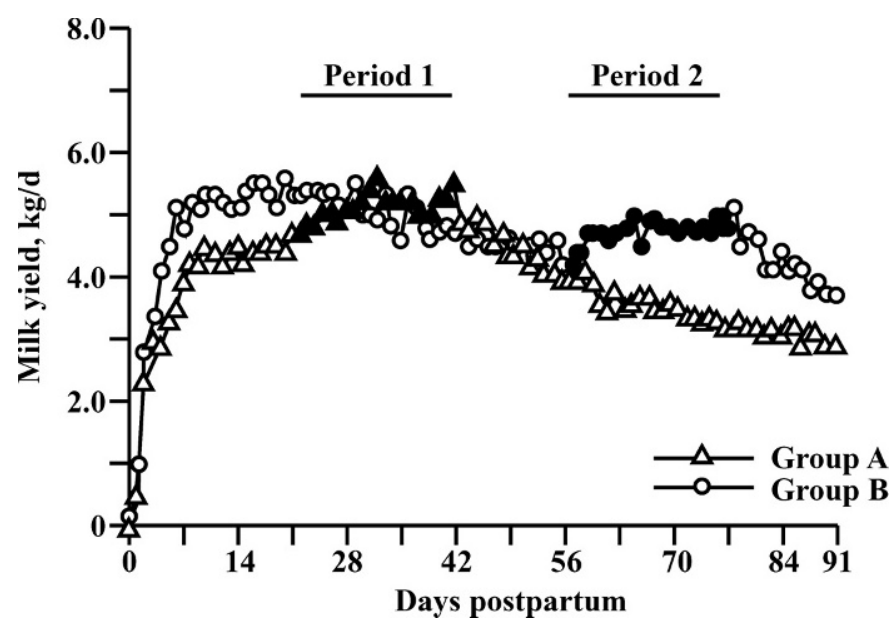

Figure 2. Changes in the averages of daily milk yield. The herds in group A received treatments of A15-DAbGHRH during period 1 and saline during period 2 , and those in group $B$ received saline and A15-DAbGHRH treatments during periods 1 and 2, respectively.

\section{Plasma GH Concentrations for $12 \mathrm{~h}$ after A15-DAbGHRH Injection}

Injection of A15-DAbGHRH induced significant increases in plasma GH concentrations (Figure 3) and GH AUC (Figure 4). In addition, the GH response to the A15-DAbGHRH injection on the final day was markedly enhanced compared with that on the first day during both periods (Figure 4).

\section{Glucose Challenge}

There were no differences in peak plasma glucose concentrations attained within 5 min after i.v. glucose injection between lactating A15-DAbGHRH-treated and saline-treated cows (data not shown). The plasma insulin concentrations following glucose challenge were higher in the A15-DAbGHRH-treated cows than in the saline-treated cows (Figure 5). The A15DAbGHRH-treated cows had significantly higher total insulin AUC than the saline-treated cows during period $1(10,236.9 \pm 440.3$ vs. $6823.0 \pm 800.1, \mu \mathrm{U} \cdot \mathrm{min} /$ $\mathrm{mL} ; P<0.01)$ and during period $2(10,166.5 \pm 819.5$ vs. $6052.6 \pm 296.5, \mu \mathrm{U} \cdot \mathrm{min} / \mathrm{mL} ; P<0.01)$. Likewise, the A15-DAbGHRH-treated cows tended to have higher net insulin AUC than the saline-treated cows (period 1: $4565.7 \pm 615.9$ vs. $3156.6 \pm 316.3, \mu \mathrm{U} \cdot \mathrm{min} /$ $\mathrm{mL} ; P<0.1$, period $2: 3972.1 \pm 693.3$ vs. $2128.6 \pm 271.2$, $\mu \mathrm{U} \cdot \mathrm{min} / \mathrm{mL} ; P<0.05)$.

\section{Insulin Challenge}

After i.v. insulin injection, the A15-DAbGHRHtreated cows had higher plasma glucose concentrations than the saline-treated cows (Figure 6). However, there were no significant differences in glucose dAUC between the animals treated with A15-DAbGHRH and saline during period $1(3812.8 \pm 401.3$ vs. $3704.8 \pm$ $431.3, \mu \mathrm{U} \cdot \mathrm{min} / \mathrm{mL})$ or during period $2(3553.3 \pm 225.1$ vs. $4022.6 \pm 424.2, \mu \mathrm{U} \cdot \mathrm{min} / \mathrm{mL})$. 
Table 2. Basal plasma concentrations of hormones and metabolites during and after daily injection of bovine GHRH analog (A15-DAbGHRH) or saline in lactating Japanese Black cows. ${ }^{1,2,3}$

\begin{tabular}{|c|c|c|c|c|c|c|}
\hline Days $\mathrm{PP}^{4}$ & $14-21$ & $\begin{array}{l}22-42 \\
(\text { period } 1)\end{array}$ & $43-49$ & $50-56$ & $\begin{array}{l}57-77 \\
(\text { period 2) }\end{array}$ & $78-84$ \\
\hline \multicolumn{7}{|l|}{ Group A } \\
\hline $\mathrm{GH}, \mathrm{ng} / \mathrm{mL}$ & $0.65 \pm 0.15$ & $1.61 \pm 0.37^{*}$ & $0.69 \pm 0.26$ & $0.52 \pm 0.08$ & $0.58 \pm 0.07$ & $0.52 \pm 0.12$ \\
\hline Insulin, $\mu \mathrm{U} / \mathrm{mL}$ & $37.3 \pm 4.1$ & $52.9 \pm 2.4^{*}$ & $42.4 \pm 1.7$ & $31.7 \pm 1.5$ & $34.9 \pm 1.8$ & $33.4 \pm 1.9$ \\
\hline Glucose, mg/dL & $64.4 \pm 2.6$ & $69.5 \pm 2.3^{\dagger}$ & $66.1 \pm 3.0$ & $63.6 \pm 2.5$ & $63.4 \pm 2.0$ & $60.2 \pm 3.3$ \\
\hline NEFA, $\mu \mathrm{Eq} / \mathrm{L}$ & $107.2 \pm 11.5$ & $109.4 \pm 15.5$ & $85.8 \pm 5.4$ & $77.6 \pm 6.7$ & $96.0 \pm 10.0$ & $87.7 \pm 11.2$ \\
\hline \multicolumn{7}{|l|}{ Group B } \\
\hline IGF-1, ng/mL & $85.6 \pm 17.8$ & $76.9 \pm 4.8$ & $79.8 \pm 7.0$ & $73.8 \pm 10.0$ & $195.4 \pm 37.7^{\dagger}$ & $165.7 \pm 30.3^{*}$ \\
\hline Insulin, $\mu \mathrm{U} / \mathrm{mL}$ & $30.8 \pm 4.9$ & $35.2 \pm 5.3$ & $31.8 \pm 6.2$ & $37.4 \pm 4.8$ & $53.0 \pm 4.8^{* *}$ & $43.0 \pm 6.6$ \\
\hline Glucose, mg/dL & $64.0 \pm 2.2$ & $64.1 \pm 1.7$ & $64.6 \pm 1.3$ & $66.9 \pm 2.0$ & $71.0 \pm 2.1^{*}$ & $70.6 \pm 1.8^{*}$ \\
\hline NEFA, $\mu \mathrm{Eq} / \mathrm{L}$ & $92.1 \pm 15.7$ & $92.3 \pm 12.7$ & $83.3 \pm 11.4$ & $91.6 \pm 13.3$ & $97.7 \pm 18.2$ & $82.6 \pm 11.7$ \\
\hline
\end{tabular}

${ }^{1}$ Group A: five cows treated with A15-DAbGHRH (period 1) and saline (period 2).

${ }^{2}$ Group B: five cows treated with saline (period 1) and A15-DAbGHRH (period 2).

${ }^{3 \dagger} P<0.1 ; * P<0.05$; and $* * P<0.01$ compared with the saline-treated group.

${ }^{4} \mathrm{PP}$ : postpartum.

\section{DISCUSSION}

Japanese Black cows, a representative beef breed in Japan, have very low milk yields. Shingu et al. (2002a) reported that these primiparous beef cows have peak lactation at 2 to $3 \mathrm{wk}$ postpartum but produce only one-tenth of the total milk production of Holstein cows. Moreover, these cows also have markedly lower GH and higher insulin secretion than Holstein cows (Shingu et al., 2002b). These hormonal characteristics suggest that manipulations to increase endogenous GH secretion and/or decrease endogenous insulin secretion may enhance milk production in these animals. Milk production may be more effectively enhanced by increasing endogenous $\mathrm{GH}$ secretion than by depressing endogenous insulin secretion. In fact, administration of exogenous GHRH induces an increase in milk yield via an enhancement of endogenous GH secretion in dairy cows (Enright et al., 1986, 1988; Lapierre et al., 1988; Dahl et al., 1990; Hodate et al., 1990). However, the responses of milk yield, hormones, and metabolites to GHRH treatment in beef breed are not yet known. Accordingly, the present report is the first to demonstrate that administration of exogenous GHRH induces an increase in milk yield with an enhancement of endogenous GH secretion in lactating beef cows. Treatment with somatotropin, but not GHRH, has been shown to stimulate milk production in other beef breeds such as Angus, Charolais, and Simmental (Armstrong et al., 1995). Likewise, Bines et al. (1980) reported that exogenous GH increased milk production and plasma $\mathrm{GH}$ concentrations in Hereford-cross beef cows. These observations suggest that GHRH and somatotropin treatments are likely to increase in milk yield and basal plasma GH levels in
Japanese Black cows. Certainly such treatments are effective in other species, for example, sheep (Hart et al., 1985), goats (Baldi et al., 2002), and dairy cows (Bauman et al., 1985; Enright et al. 1986, 1988; Dahl et al., 1991).

Increased milk production after GH treatment is likely partially a result from IGF-1-mediated effects on the udder (Peel and Bauman, 1987; Bauman and Vernon, 1993; Burton et al., 1994; Bauman, 1999). In fact, both type 1 and type 2 IGF receptors are present in bovine mammary tissue (Dehoff et al., 1988). The mRNA for GH receptor has been identified in mammary tissue (Hauser et al., 1990; Plath-Gabler et al., 2001), although a functional GH receptor has not been identified (Akers, 1985; Gluckman et al., 1987; Collier et al., 1989). In addition, somatotropin or GHRH treatment increases circulating IGF-1 in lactating dairy cows (Peel and Bauman, 1987; Dahl et al., 1990; Hodate et al., 1990, 1991; Sharma et al., 1994; Vanderkooi et al., 1995). Close-arterial infusion of the mammary gland with bovine somatotropin had no effect on milk yield, whereas close-arterial infusion of IGF-1 stimulated milk yield in sheep and goats [see Bauman (1999) for a review]. Thus, IGF-1 is likely important in the galactopoietic actions of GH. In the present study, the treatment of GHRH analog induced the marked release of endogenous $\mathrm{GH}$ and stimulated subsequent increases in plasma IGF-1 concentrations and milk production.

During both periods 1 and 2, exogenous GHRH more effectively stimulated $\mathrm{GH}$ secretion on the final days (d 42 and 77 postpartum) than on the first days (d 22 and 57 postpartum), as shown in Figures 3 and 4 . In lactating dairy cows consecutively treated with 

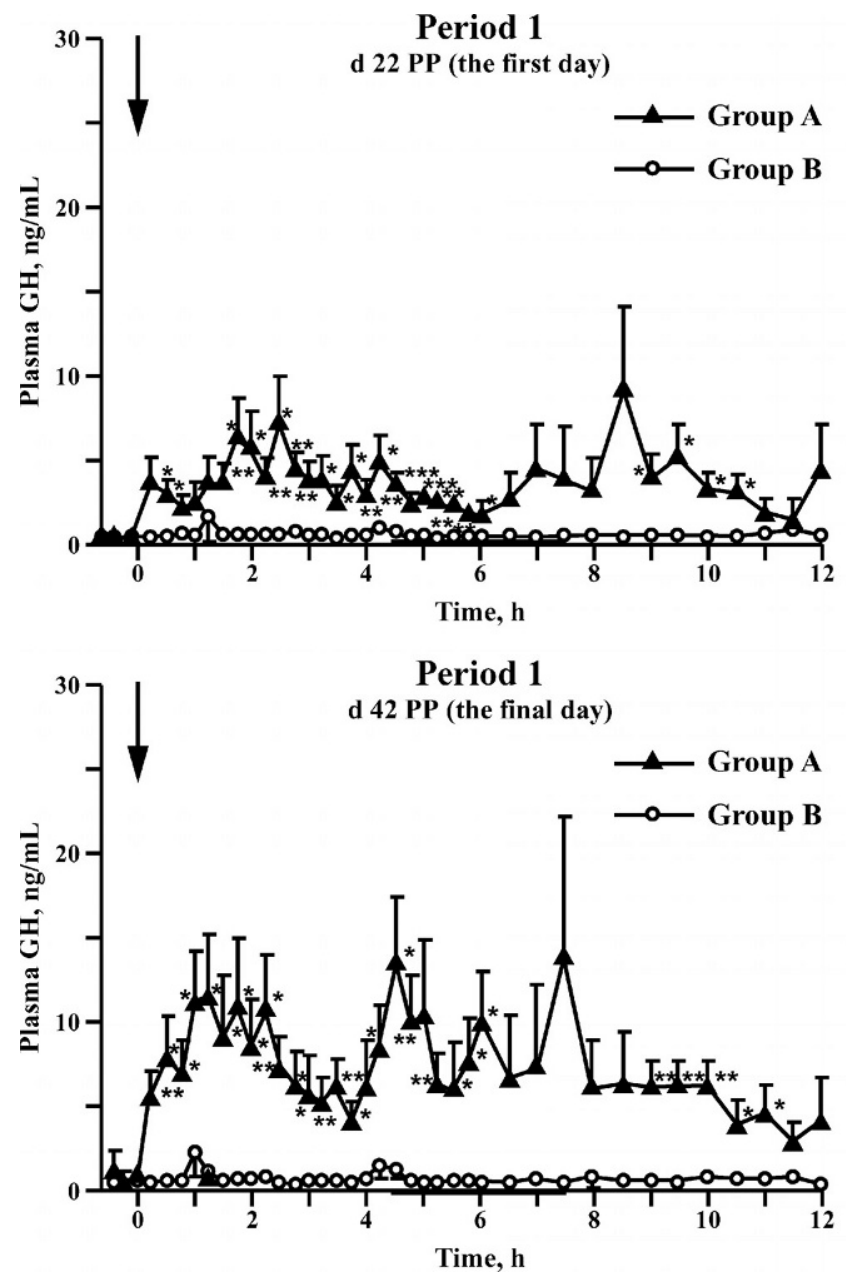

Period 2 d 57 PP (the first day)

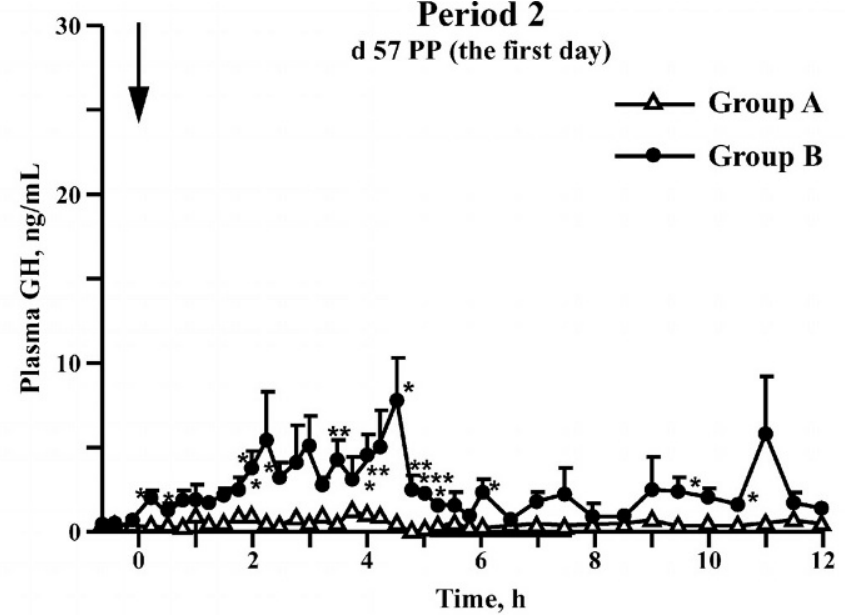

Period 2

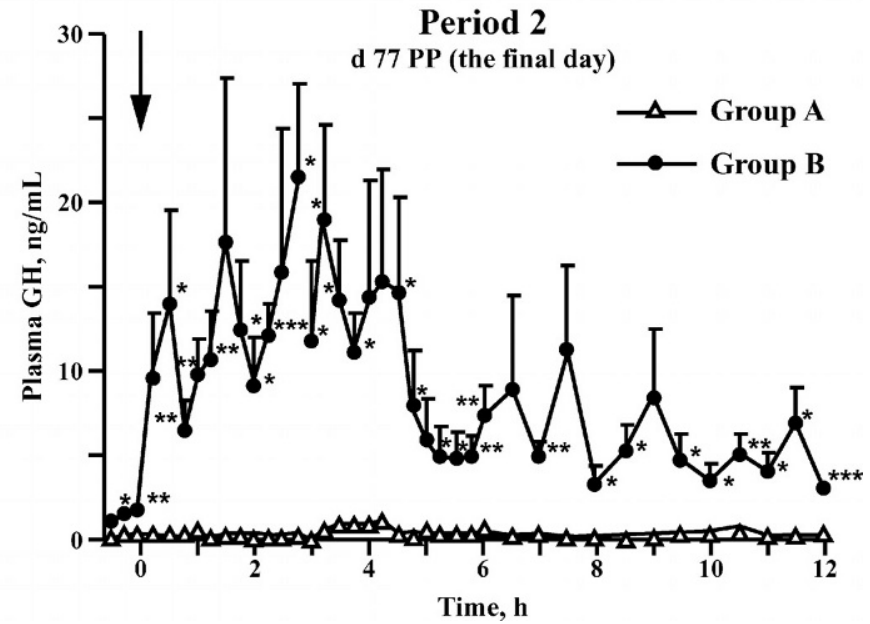

Figure 3. Plasma growth hormone (GH) concentrations after a daily s.c. A15-DAbGHRH or saline (control) injection in groups A and B during periods 1 (left panels) and 2 (right panels). Each arrow indicates the time of A15-DAbGHRH or saline injection. Asterisks indicate significant differences: ${ }^{*} P<0.05 ; * * P<0.01$; and $* * * P<0.001$ compared with the corresponding values for saline-treated cows. The bold bars on the $\mathrm{x}$-axis represent evening feeding time. PP: postpartum.

GHRH, there is no detectable desensitization of $\mathrm{GH}$ release (Enright et al., 1986, 1988; Lapierre et al., 1988; Dahl et al., 1990; Hodate et al., 1990; Binelli et al., 1995). An in vitro study with rats showed that immuno-neutralization of endogenous GHRH elicits a marked decrease in pituitary GH mRNA (Chihara et al., 1994). Moreover, incubation of cultures of pituitary cells with GHRH promotes an increase in GH mRNA levels (Gick et al., 1984). These results suggest that GHRH might contribute to the GH synthesis in somatotrophs of the pituitary gland in addition to stimulating GH release. Thus, consecutive GHRH treatment does not apparently elicit desensitization of GH release in lactating Japanese Black cows.

The reported effects of somatotropin treatment on plasma insulin and glucose in lactating beef cows are controversial (Schams et al., 1991; Armstrong et al.,
1995). However, the present results clearly demonstrate that once daily GHRH administration for $21 \mathrm{~d}$ increased the basal plasma insulin and glucose concentrations and enhanced insulin secretion without inducing significant differences in peak glucose levels at glucose challenge. These results indicate that GHRH treatment induces hyperinsulinemia and hyperglycemia, suggesting that GHRH treatment may cause insulin resistance in lactating Japanese Black cows. During lactation, somatotropin administration induces increases in circulating insulin and glucose concentrations in Hereford-cross (Bines et al., 1980), Angus, Charolais, and Simmental cows (Armstrong et al., 1995), although it has remained unknown whether these changes after GHRH treatment are induced in beef breeds. In lactating dairy cows, somatotropin treatment induces an increase in plasma insulin levels 


\section{Period 1}

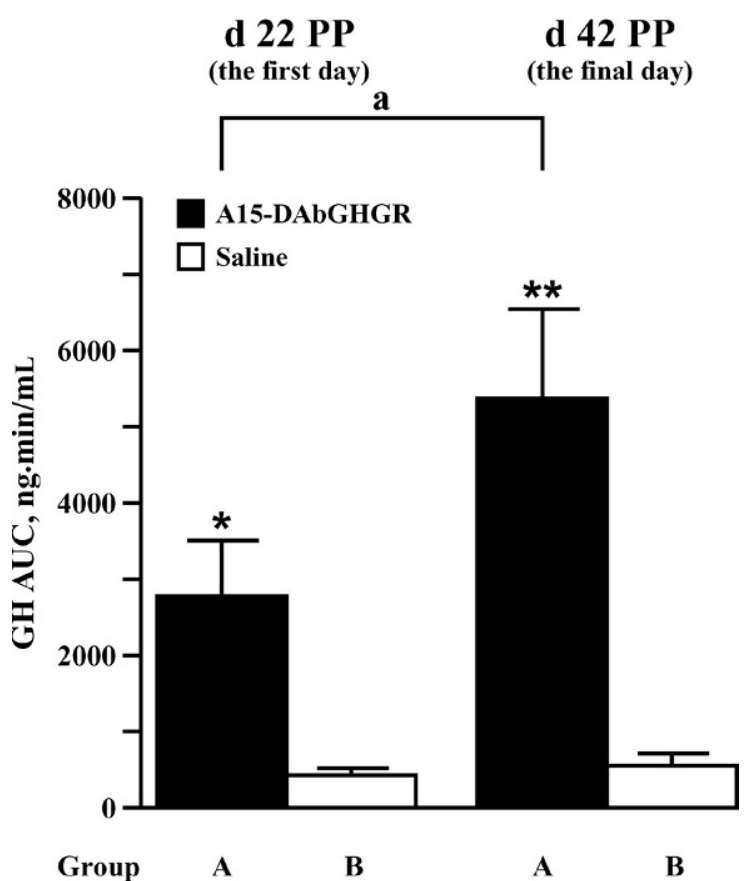

Period 2

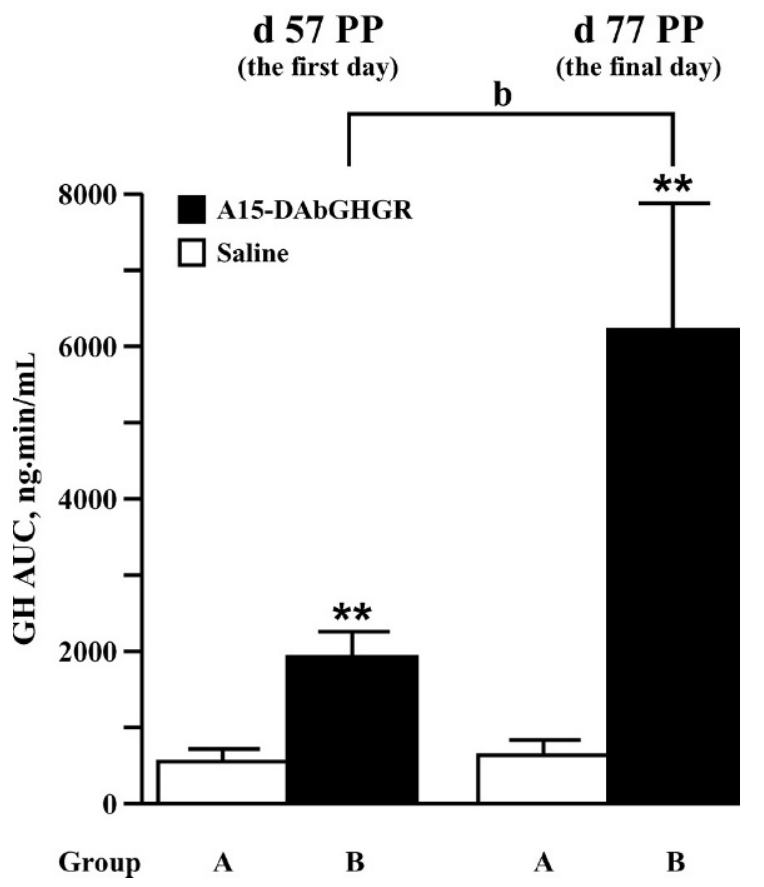

Figure 4. The area under the response curve (AUC) of growth hormone $(\mathrm{GH})$ released in response to s.c. A15-DAbGHRH and saline injection on the first and final days of periods 1 (upper panel) and 2 (bottom panel). Asterisks indicate significant differences: $* P<0.05$; and $* * P<0.01$ compared with the corresponding values for salinetreated cows. The small letters on the lines connecting the first and final days represent the $P$-values; (a) $P=0.095$, (b) $P=0.039$. PP: postpartum
Period 1 (d 38 PP)

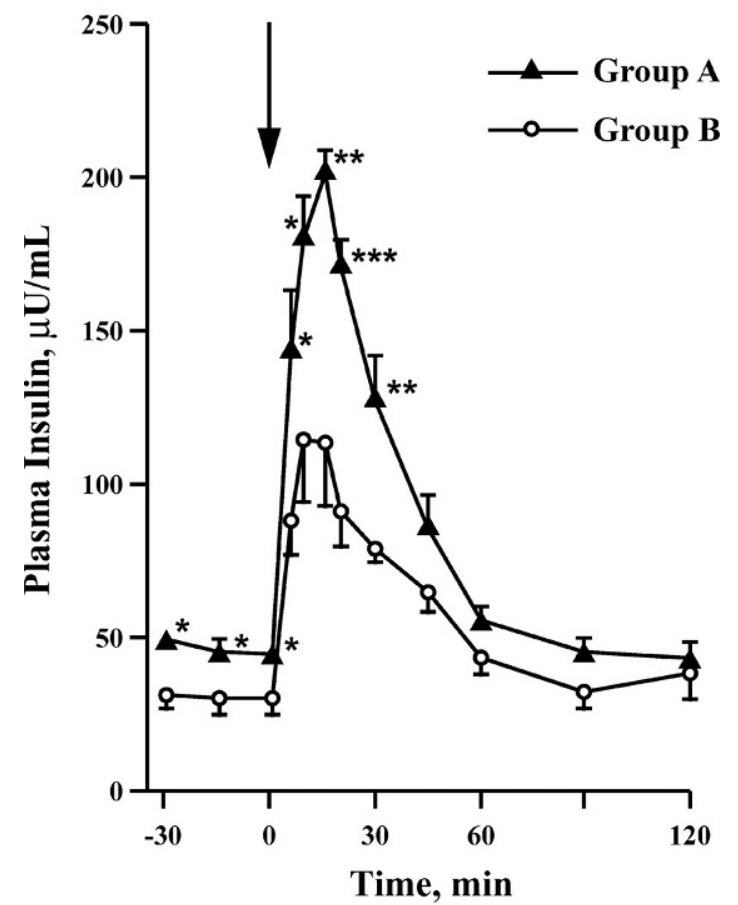

Period 2 (d 73 PP)

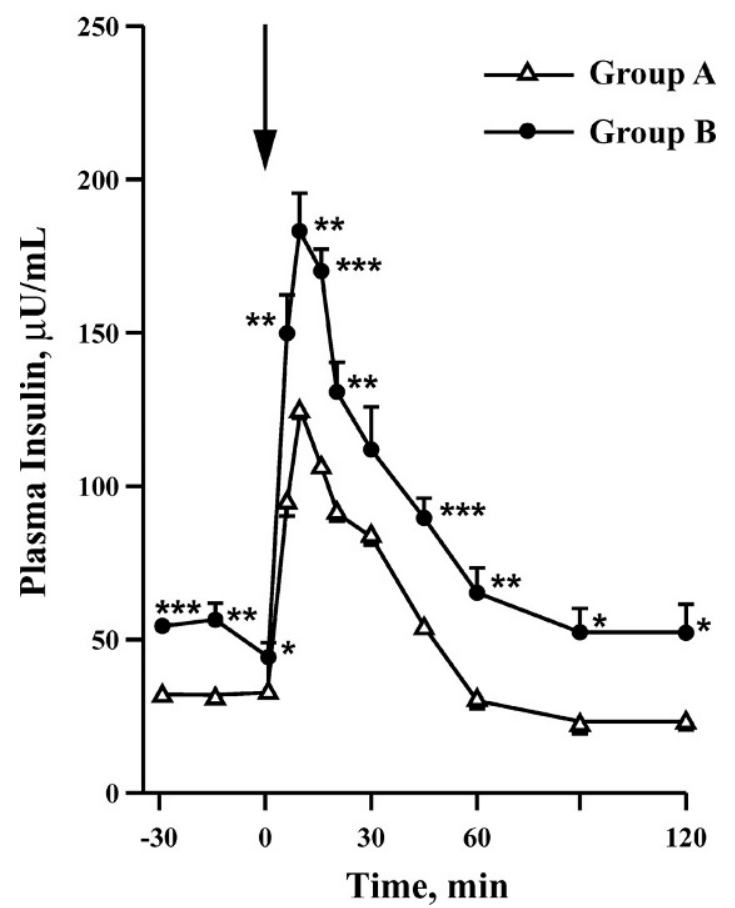

Figure 5. Plasma insulin concentrations after i.v. glucose injection (112.5 mg/kg of BW) in groups A and B during periods 1 (upper panel) and 2 (bottom panel). Each arrow indicates the time of glucose plus s.c. A15-DAbGHRH or saline injections. Asterisks indicate significant differences: $* P<0.05$; and $* * P<0.01$ compared with the corresponding values for saline-treated cows. PP: postpartum. 

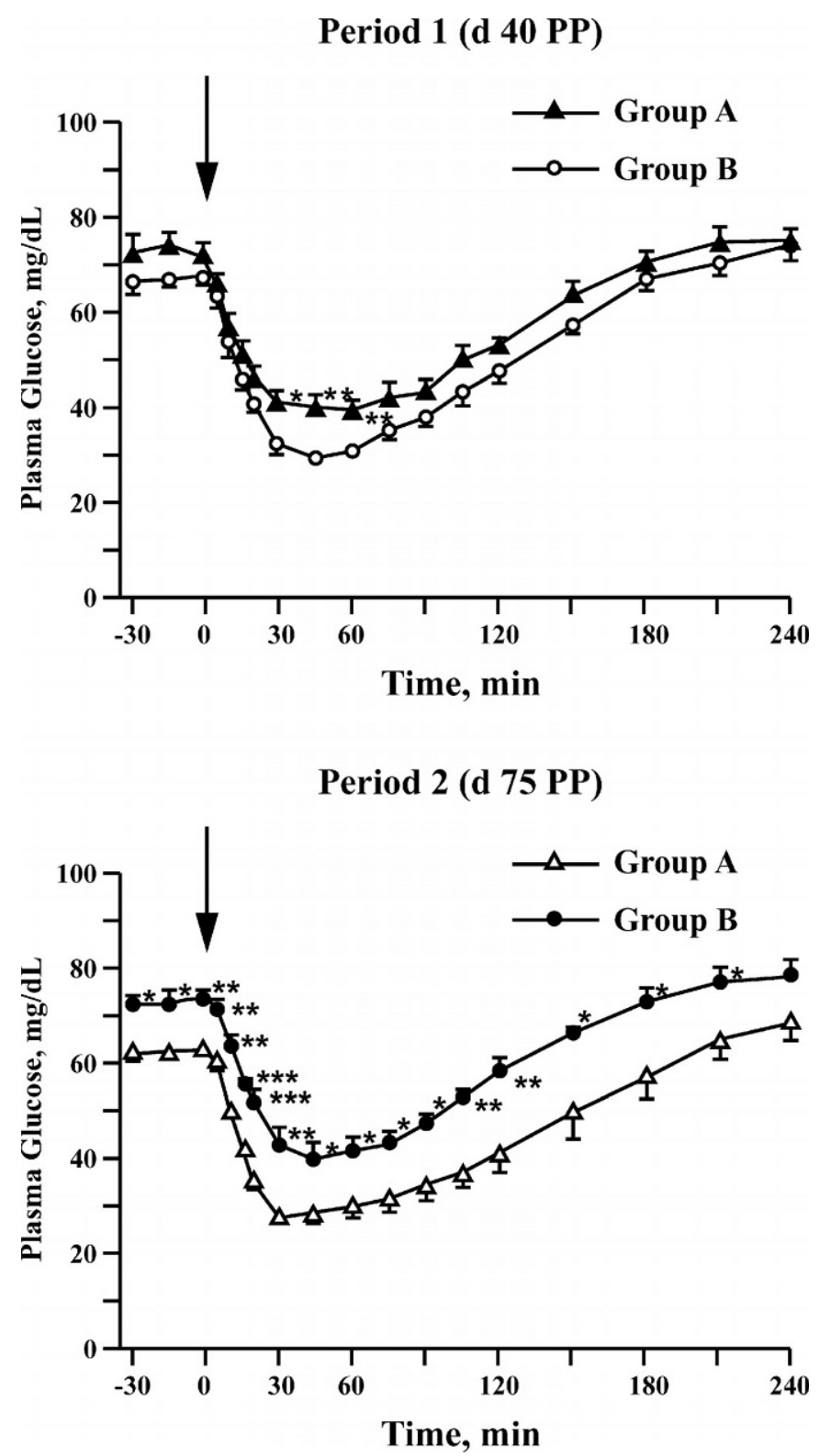

Figure 6. Plasma glucose concentrations in response to i.v. insulin injection (0.2 U/kg of BW) in groups A and Group B during periods 1 (upper panel) and 2 (bottom panel). Each arrow indicates the time of insulin plus s.c. A15-DAbGHRH or saline injections. Asterisks indicate significant differences: $* P<0.05$; and $* * P<0.01$ compared with the corresponding values for saline-treated cows. PP: postpartum.

(McDowell et al., 1987; McGuire et al., 1998) and reduces the sensitivity of body tissues to insulin (McCutcheon and Bauman, 1986; Sechen et al., 1990). This suggests glucose sparing for the enhancement of milk production in dairy cows. In the present study, however, there were no significant differences in glucose dAUC between Japanese Black cows treated with A15DAbGHRH and saline, indicating an unchanged sensi- tivity of body tissues to insulin. Given the low milk production in Japanese Black cows (Shingu et al., 2002a), this maintenance of insulin sensitivity during lactation might contribute to the lactational performance in these animals. However, because the changes in plasma glucose concentrations and dAUC after insulin challenge result from a balance between the rates of glucose utilization and production, further investigations of glucose kinetics are needed.

One of the effects of GH is a decrease in lipid synthesis when in positive energy balance and an increase in lipolysis when in negative balance in lactating dairy breeds [see Bauman (1999) for a review]. This suggests that the lipolytic effects of GH depend on the energy balance. For example, there was a direct relationship between negative energy balance and increased NEFA concentrations in GHRH-treated cows (Dahl et al., 1991), and plasma NEFA concentrations were unaffected when short-term GH-treated dairy cows were in positive energy balance during lactation (Eppard et al., 1985; McCutcheon and Bauman, 1986). In the present study with lactating Japanese Black cows, GHRH treatment for $21 \mathrm{~d}$ induced no significant increase in plasma NEFA concentrations. These results might have reflected a positive energy balance. In fact, BW losses were not observed in these cows during the experimental period (data not shown).

The proportions of milk components (milk fat, milk protein, and lactose) remained unchanged in lactating Japanese Black cows treated with A15-DAbGHRH, in agreement with the reports in dairy cattle treated with GHRH (Enright et al., 1986; Hodate et al., 1990).

In conclusion, during lactation, GHRH analog treatment facilitates endogenous GH and IGF-1 secretion in typically low milk producing Japanese Black cows, leading to an enhancement in milk yield and increases in plasma insulin and glucose concentrations without alterations of milk components.

\section{ACKNOWLEDGMENTS}

The authors express appreciation to K. Mitani (National Institute of Animal Health) and T. Narita (National Institute of Livestock and Grassland Science) for the analysis of milk components, colleagues at Field Management Section 2 (Department of Research Planning and Coordination in National Agricultural Research Center for Tohoku Region) for the technical assistance and animal management, and S. Osaki for the laboratory assistance.

\section{REFERENCES}

Akers, R. M. 1985. Lactogenic hormones: Binding sites, mammary growth, secretory cell differentiation, and milk biosynthesis in ruminants. J. Dairy Sci. 68:501-519. 
Armstrong, J. D., R. W. Harvey, M. A. Poore, R. B. Simpson, D. C. Miller, G. M. Gregory, and G. F. Hartnell. 1995. Recombinant bovine somatotropin increases milk yield and calf gain in diverse breeds of beef cattle: Associated changes in hormones and indices of metabolism. J. Anim. Sci. 73:3051-3061.

Baldi, A., S. Modina, F. Cheli, F. Gandolfi, L. Pinotti, L. B. Scesi, F. Fantuz, and V. Dell'Orto. 2002. Bovine somatotropin administration to dairy goats in late lactation: Effects on mammary gland function, composition and morphology. J. Dairy Sci. 85:1093-1102.

Bauman, D. E., and W. B. Currie. 1980. Partitioning of nutrients during pregnancy and lactation: A review of mechanisms involving homeostasis and homeorhesis. J. Dairy Sci. 63:1514-1529.

Bauman, D. E., P. J. Eppard, M. J. DeGeeter, and G. M. Lanza. 1985. Responses to high-producing dairy cows to long-term treatment with pituitary somatotropin and recombinant somatotropin. J. Dairy Sci. 68:1352-1362.

Bauman, D. E. 1992. Bovine somatotropin: Review of an emerging animal technology. J Dairy Sci. 75:3432-3451.

Bauman, D. E., and R. G. Vernon. 1993. Effects of exogenous bovine somatotropin on lactation. Annu. Rev. Nutr. 13:437-461.

Bauman, D. E. 1999. Bovine somatotropin and lactation: From basic science to commercial application. Domest. Anim. Endocrinol. 17:101-116.

Binelli, M., W. K. Vanderkooi, L. T. Chapin, M. J. VandeHaar, J. D. Turner, W. M. Moseley, and H. A. Tucker. 1995. Comparison of growth hormone-releasing factor and somatotropin: Body growth and lactation of primiparous cows. J. Dairy Sci. 78:2129-2139.

Bines, J. A., I. C. Hart, and S. V. Morant. 1980. Endocrine control of energy metabolism in the cow: The effect on milk yield and levels of some blood constituents of injecting growth hormone and growth hormone fragments. Br. J. Nutr. 43:179-188.

Burton, J. L., B. W. McBride, E. Block, D. R. Glimm, and J. J. Kennelly. 1994. A review of bovine growth hormone. Can. J. Anim. Sci. 74:167-201.

Chihara, K., T. Uchiyama, S. Shakutsui, H. Kaji, Y. Okimura, and H. Abe. 1994. Molecular genetics of growth hormone-releasing factors. Horm. Res. 42:182-188.

Collier, R. J., S. Ganguli, P. T. Menke, F. C. Buonomo, M. F. McGrath, C. E. Kotts, and G. G. Krivi. 1989. Changes in insulin and somatomedin receptors and uptake of insulin, IGF-1 and IGF-2 during mammary growth, lactogenesis and lactation. Pages 153-163 in Biotechnology in Growth Regulation. R. B. Heap, C. G. Prosser, and G. E. Lamming, eds. Butterworths, London, UK.

Dahl, G. E., L. T. Chapin, S. A. Zinn, W. M. Moseley, T. R. Schwartz, and H. A. Tucker. 1990. Sixty-day infusions of somatotropinreleasing factor stimulate milk production in dairy cows. J. Dairy Sci. 73:2444-2452.

Dahl, G. E., L. T. Chapin, M. S. Allen, W. M. Moseley, and H. A. Tucker. 1991. Comparison of somatotropin and growth hormonereleasing factor on milk yield, serum hormones, and energy status. J. Dairy Sci. 74:3421-3428.

Dehoff, M. H., R. G. Elgin, R. J. Collier, and D. R. Clemmons. 1988 Both type 1 and 2 insulin-like growth factor receptor binding increase during lactogenesis in bovine mammary tissue. Endocrinology 122:2412-2417.

Enright, W. J., L. T. Chapin, W. M. Moseley, S. A. Zinn, and H. A. Tucker. 1986. Growth hormone-releasing factor stimulates milk production and sustains growth hormone release in Holstein cows. J. Dairy Sci. 69:344-351.

Enright, W. J., L. T. Chapin, W. M. Moseley, and H. A. Tucker. 1988. Effects of infusions of various doses of bovine growth hormonereleasing factor on growth hormone and lactation in Holstein cows. J. Dairy Sci. 71:99-108.

Eppard, P. J., D. E. Bauman, and S. N. McCutcheon. 1985. Effect of dose of bovine growth hormone on lactation of dairy cows. J. Dairy Sci. 68:1109-1115.

Gick, G. G., F. N. Zeytin, P. Brazeau, N. C. Ling, F. S. Esch, and C. Bancroft. 1984. Growth hormone-releasing factor regulates growth hormone mRNA in primary cultures of rat pituitary cells. Proc. Natl. Acad. Sci. USA 81:1553-1555.

Gluckman, P. D., B. H. Breier, and S. R. Davis. 1987. Physiology of the somatotropic axis with particular reference to the ruminant. J. Dairy Sci. 70:442-466.

Hart, I. C., J. A. Bines, C. C. Balch, and A. T. Cowie. 1975. Hormone and metabolite differences between lactating beef and dairy cattle. Life Sci. 16:1285-1292.

Hart, I. C., P. M. E. Chadwick, S. James, and A. D. Simmonds. 1985. Effect of intravenous bovine growth hormone or human pancreatic growth hormone-releasing factor on milk production and plasma hormones and metabolites in sheep. J. Endocrinol. 105:189-196.

Hauser, S. D., M. F. McGrath, R. J. Collier, and G. G. Krivi. 1990. Cloning and in vivo expression of bovine growth hormone receptor mRNA. Mol. Cell Endocrinol. 72:187-200.

Hodate, K., T. Johke, A. Ozawa, and S. Ohashi. 1990. Plasma growth hormone, insulin-like growth factor-1, and milk production responses to exogenous human growth hormone-releasing factor analogs in dairy cows. Endocrinol. Jpn. 37:261-273.

Hodate, K., A. Ozawa, and T. Johke. 1991. Effect of a prolonged release formulation of recombinant bovine somatotropin on plasma concentrations of hormones and metabolites, and milk production in dairy cows. Endocrinol. Jpn. 38:527-532.

Japanese Feeding Standard for Beef Cattle. 1995. Agriculture, Forestry and Fisheries Research Council Secretariat, MAFF. Central Association of Livestock Industry, Tokyo, Japan.

Johke, T. 1978. Effects of TRH on circulating growth hormone, prolactin and triiodothyronine levels in the bovine. Endocrinol. Jpn. 25:19-26.

Lapierre, H., G. Pelletier, D. Petitclerc, P. Dubreeuil, J. Morisset, P. Gaudreau, Y. Couture, and P. Brazeau. 1988. Effect of twomonth treatment with growth hormone-releasing factor on growth hormone release in dairy cows. Can. J. Anim. Sci. 68:731-740

McCutcheon, S. N., and D. E. Bauman. 1986. Effect of chronic growth hormone treatment on responses to epinephrine and thyrotropin-releasing hormone in lactating cows. J. Dairy Sci. 69:44-51.

McDowell, G. H., I. C. Hart, J. A. Bines, D. B. Lindsay, and A. C. Kirby. 1987. Effects of pituitary-derived bovine growth hormone on production and parameters and biokinetics of key metabolites in lactating dairy cows at peak and mid-lactation. Aust. J. Biol. Sci. 40:191-202.

McGuire, M. A., D. A. Dwyer, D. E. Bauman, and D. F. Smith. 1998. Insulin-like growth factors in plasma and afferent mammary lymph of lactating cows deprived of feed or treated with bovine somatotropin. J. Dairy Sci. 81:950-957.

Ozawa, A., K. Hodate, S. Miyamoto, F. Ohtani, T. Tsushima, and T. Johke. 1991. Plasma profiles of insulin-like growth factor-1 for 24 hours and after injection of bovine growth hormone in dairy heifers. Anim. Sci. Technol. 62:933-938.

Peel, C. J., and D. E. Bauman. 1987. Somatotropin and lactation. J. Dairy Sci. 70:474-486.

Plath-Gabler, A., C. Gabler, F. Sinowatz, B. Berisha, and D. Schams. 2001. The expression of the IGF family and GH receptor in the bovine mammary gland. J. Endocrinol. 168:39-48.

Schams, D., F. Graf, J. Meyer, B. Graule, M. Mauthner, and C. Wollny. 1991. Changes in hormones, metabolites, and milk after treatment with sometribove (recombinant methionyl bST) in Deutsches Fleckvieh and German Black and White cows. J. Anim. Sci. 69:1583-1592.

Sechen, S. J., F. R. Dunshea, and D. E. Bauman. 1990. Somatotropin in lactating cows: Effect on response to epinephrin and insulin. Am. J. Physiol. 258 (Endocrinol. Metab. 21):E582-E588.

Sharma, B. K., M. J. VandeHaar, and N. K. Ames. 1994. Expression of insulin-like growth factor-1 in cows at different stages of lactation and in late lactation cows treated with somatotropin. J. Dairy Sci. 77:2232-2241.

Shingu, H., K. Hodate, S. Kushibiki, Y. Ueda, A. Watanabe, M. Shinoda, and M. Matsumoto. 2001. Profiles of growth hormone and insulin secretion, and glucose response to insulin in growing 
Japanese Black heifers (beef type): comparison with Holstein heifers (dairy type). Comp. Biochem. Physiol. 130C:259-270.

Shingu, H., K. Hodate, S. Kushibiki, Y. Ueda, A. Watanabe, and M. Matsumoto. 2002a. Profiles of milk yield and milk composition in lactating Japanese Black and Japanese Shorthorn cows. Bull. Natl. Agric. Res. Cent. Tohoku Reg. 100:61-66.

Shingu, H., K. Hodate, S. Kushibiki, Y. Ueda, A. Watanabe, M. Shinoda, and M. Matsumoto. 2002b. Breed differences in growth hormone and insulin secretion between lactating Japanese Black cows (beef type) and Holstein cows (dairy type). Comp. Biochem. Physiol. 132C:493-504.

Vanderkooi, W. K., M. J. VandeHaar, B. K. Sharma, M. Binelli, H. A. Tucker, R. M. Akers, and W. M. Moseley. 1995. Comparison of growth hormone-releasing factor and somatotropin: The somatotropic axis in lactating primiparous cows. J. Dairy Sci. 78:2140-2149. 